\title{
Comparison of fluorgestone and medroxyprogesterone intravaginal sponges for oestrus synchronization in Saanen does during the transition period
}

\author{
I. Dogan $^{1 \#}$, Z. Nur ${ }^{1}$, U. Gunay ${ }^{1}$, M.K. Soylu ${ }^{1}$ and C. Sonmez ${ }^{2}$ \\ ${ }^{1}$ Uludag University, Faculty of Veterinary Medicine, Department of Reproduction \& Artificial Insemination, Gorukle \\ 16059, Bursa-Turkey \\ ${ }^{2}$ Vetifarm Veteriner Ilaclari Tic. A.S. Harbiye, Istanbul-Turkey
}

\begin{abstract}
The efficiency of medroxyprogesterone acetate (MAP) and fluorogestone acetate (FGA) sponges for synchronizing oestrus in lactating Saanen goats was investigated during the transition from non-breeding to natural breeding season. Does were treated for 11 days with $60 \mathrm{mg}$ MAP ( $\mathrm{n}=19)$ or $40 \mathrm{mg}$ FGA ( $\mathrm{n}=24)$ sponges. All does received intramuscular injections of $750 \mathrm{IU}$ pregnant mare serum gonadotrophin (PMSG) and $125 \mu \mathrm{g}$ cloprostenol $\left(\mathrm{PGF}_{2} \alpha\right) 48 \mathrm{~h}$ prior to sponge removal. Cervical artificial insemination (AI) with fresh diluted semen was performed at a fixed time $(36$ and $48 \mathrm{~h})$ followed progestagen withdrawal. The two progestagen treatments showed no significant difference in oestrous response (100\% both for MAP and FGA groups), time to the onset (15.8 \pm 09 and $15.0 \pm 06 \mathrm{~h}$ for the MAP and FGA groups, respectively), duration (30.5 \pm 1.9 and $34.0 \pm 1.4 \mathrm{~h}$ for MAP and FGA, respectively) and cessation (42.32 \pm 1.6 and $43.25 \pm 1.3 \mathrm{~h}$ for MAP and FGA, respectively) of the induced oestrus period. No significant difference was observed with respect to pregnancy rates determined at the $53^{\text {rd }}$ day after AI (52.6 and 50.0\% for MAP and FGA, respectively). These dates indicate that the use of MAP and FGA intravaginal progestagen treatments are equally efficient in synchronizing oestrus in lactating goats during the transition from the non-breeding to the natural breeding season.
\end{abstract}

Keywords: Goat, oestrus, synchronization, medroxyprogesterone acetate, MAP, fluorogestone acetate, FGA ${ }^{\#}$ Corresponding author. E-mail address: idogan@uludag.edu.tr

\section{Introduction}

The majority of goat breeds shows seasonality in their reproductive activities (Chemineau et al., 1992). Therefore, synchronization of oestrus is an important management tool that has been used as an aid for artificial insemination (AI) and to reduce seasonal effects in the reproduction of dairy goats (Freitas et al., 1997). In order to achieve this goal, progesterone or a progestagen analogue is usually used to synchronize oestrus in goats during the breeding and non-breeding season (Ak et al., 1998). Both progesterone and its analogues have an inhibitory effect in the release of luteinizing hormone (LH) from the anterior pituitary so that the endocrine events that influence the maturation of the ovarian preovulatory follicles and their later ovulation are suppressed. Hence, following withdrawal of progesterone, oestrus and ovulation occur at a predictable period of time (Bretzlaff, 1997; Leboeuf et al., 1998). Worldwide, the most common route of application of progestagens in goats is intravaginal (Bretzlaff, 1997). Two of the types of intravaginal sponges (pessaries) commonly used for synchronization and/or induction of oestrus in does are medroxyprogesterone acetate (MAP) and fluorogestone acetate (FGA) (Baril et al., 1993; Romano, 1996; Ak et al., 1998; Romano, 1998; Motlomelo et al., 2002). Even though some studies have found these two progestagens to be equally effective in the induction of oestrus, ovulation and fertility (Gordon, 1975; Smith et al., 1981), some researchers have favoured fluorogestone acetate (Boland et al., 1978; Alifakiotis et al., 1982).

Pregnant mare serum gonadotrophin (PMSG) administration with follicle stimulating hormone (FSH) and (LH) activity $48 \mathrm{~h}$ before or at progestagen withdrawal have been shown to stimulate follicular growth in both anoestrous and cycling goats and affect the time of ovulation (Bretzlaff, 1997; Leboeuf et al., 1998). Pregnant mare serum gonadotrophin is generally administered at the time of progestagens removal during the breeding season (Motlomelo et al., 2002). During the non-breeding season, PMSG is administered $48 \mathrm{~h}$ prior to progestagen removal (Baril et al., 1993). At the same time the use of the synthetic prostaglandin $\mathrm{F}_{2 \alpha}$, analogue, cloptostenol, causes luteolysis in does having a functional corpus luteum at the end of the treatment (Baril et al., 1993; Bretzlaff, 1997; Leboeuf et al., 1998; Motlomelo et al., 2002). 
The objective of the present study was to compare the efficiency of MAP and FGA in synchronizing oestrus in lactating Saanen goats during the transition period from non-breeding to natural breeding season and compare the fertility rates obtained following AI at the induced oestrus.

\section{Materials and Methods}

The study was carried out at a farm located in Balikesir (latitude $39^{\circ} 06^{\prime}$ and $40^{\circ} 39^{\prime} \mathrm{N}$, longitude $26^{\circ}$ $39^{\prime}$ and $28^{\circ} 58^{\prime} \mathrm{E}$, altitude $139 \mathrm{~m}$ ) in western Turkey during June (the transition from non-breeding to natural breeding season in the region) under natural lighting. Forty-three lactating Saanen does two to five years of age and weighing between 35 to $85 \mathrm{~kg}$ with good body conditions (BCS: 2.00 to 5.00) were used in this study. The does were allowed to graze on natural pasture from 07:30 to 19:30 and kept overnight in pens. In addition, does were fed $350 \mathrm{~g}$ of a balanced concentrate/doe/day. A mineral lick and water was available $a d$ libitum. All lactating does were machine-milked once a day at 20:00. The management of the does did not change throughout the entire experimental period.

The experimental does were divided into two groups according to age, milk yield and body weight. Oestrus was synchronized with $60 \mathrm{mg}$ MAP $(\mathrm{n}=24$, Vetimex, Bladel, Netherlands) or $40 \mathrm{mg}$ FGA ( $\mathrm{n}=19$, Intervet, Netherlands) intravaginal sponges. The sponges were left in situ for 11 days. All goats also received an intramuscular injection of 750 IU PMSG (Intervet, Netherlands) and $125 \mu \mathrm{g}$ of cloprostenol (estroPLAN, Parnell Laboratories, Austria) $48 \mathrm{~h}$ prior to progestagen withdrawal. Oestrus was detected with the aid of teaser bucks every six hours from 12 to $60 \mathrm{~h}$ following progestagen withdrawal. The male considered the does in oestrous when they allowed mounting. Oestrus duration was defined as the time elapsed between the first and last accepted mount within the same oestrus period. Oestrus cessation was defined as the time elapsed between sponge removal and last accepted mount within the same oestrous period.

One Saanen buck of proven fertility was used for semen collection in order to minimize the effect of buck variation. The semen was collected by artificial vagina in the presence of a doe in oestrus. During collection and examination the semen was protected from temperature shock. Each ejaculate was immediately evaluated for volume, wave motility and concentration. Only ejaculates with a volume higher than $0.5 \mathrm{~mL}$ and good wave motility were used. The volume was recorded from the collection tube, which was graduated in $0.1 \mathrm{~mL}$ divisions and the motility was assessed by depositing a drop of semen on a glass slide and examining it on a warm stage $\left(35^{\circ} \mathrm{C}\right)$ under the microscope $(\mathrm{x} 40)$. The semen sample was scored using a scale ranging from 0 (no wave movement) to 5 (extreme wave movement). Only ejaculates with scores of 3 and higher were used. The semen was diluted to a sperm concentration of $600 \times 10^{6}$ motile cells $/ \mathrm{mL}$ after being counted with the aid of a haemocytometer. A one-step dilution was performed at $30{ }^{\circ} \mathrm{C}$ with the addition of sterilized cow skim milk containing $1000 \mathrm{IU}$ sodium G penicillin and $1000 \mu \mathrm{g} / \mathrm{mL}$ dihydrostreptomycine sulphate. The diluted semen was cooled to $5{ }^{\circ} \mathrm{C}$ over a two hour period and kept at this temperature until insemination. Each doe (whether in oestrus or not) was inseminated intracervically twice at 36 and $48 \mathrm{~h}$ following sponge withdrawal, with a $0.25 \mathrm{~mL}$ straw containing 150 million spermatozoa. All does were tested for pregnancy 53 days after AI with the aid of a trans-abdominal ultrasonic scanning apparatus.

Oestrous response, onset of oestrus, duration of oestrus, cessation of oestrus and pregnancy rates were compared between groups using the Mann-Whitney U test. The 95\% significance level was noted. The SPSS 10.0 software was used for all statistical analyses.

\section{Results and Discussion}

The oestrous response and pregnancy rate following oestrous synchronization and fixed time AI are set out in Table 1. All does in both treatment groups showed oestrus after sponge removal. The mean interval from sponge withdrawal to onset of oestrus was $15.8 \pm 0.9$ and $15.0 \pm 0.6 \mathrm{~h}$ for the MAP and FGA groups, respectively. Oestrus duration was $30.5 \pm 1.9$ and $34.0 \pm 1.4 \mathrm{~h}$ for the MAP and FGA groups, respectively. Oestrus cessation occurred at $42.32 \pm 1.6$ and $43.25 \pm 1.3 \mathrm{~h}$ following sponge withdrawal for the same groups, respectively. Pregnancy rates at day 53 after AI for the MAP and FGA groups were 52.63 and 50.0\%, respectively. None of these differences were significant, as demonstrated in Table 1. 
Table 1 Response of Saanen does to oestrus synchronization with medroxyprogesterone acetate (MAP) and fluorogestone acetate (FGA) and artificial insemination

\begin{tabular}{|c|c|c|c|c|c|c|}
\hline \multirow{2}{*}{$\begin{array}{l}\text { Treatment } \\
\text { group }\end{array}$} & \multirow{2}{*}{$\begin{array}{l}\text { No. of } \\
\text { does } \\
\text { (n) }\end{array}$} & \multicolumn{4}{|c|}{ Oestrous response* } & \multirow{2}{*}{$\begin{array}{c}\text { Pregnancy } \\
\text { rate* } \\
(\%)\end{array}$} \\
\hline & & $(\%)$ & $\begin{array}{c}\text { Onset } \\
\text { Mean } \pm \text { s.e. } \\
\text { (h) }\end{array}$ & $\begin{array}{l}\text { Duration } \\
\text { Mean } \pm \text { s.e. } \\
\text { (h) }\end{array}$ & $\begin{array}{l}\text { Cessation } \\
\text { Mean } \pm \text { s.e. } \\
\text { (h) }\end{array}$ & \\
\hline MAP & 19 & 100 & $15.8 \pm 0.9$ & $30.5 \pm 1.9$ & $42.32 \pm 1.6$ & 52.63 \\
\hline FGA & 24 & 100 & $15.0 \pm 0.6$ & $34.0 \pm 1.4$ & $43.25 \pm 1.3$ & 50.0 \\
\hline Total & 43 & 100 & $15.4 \pm 0.5$ & $32.5 \pm 1.2$ & $42.8 \pm 1.0$ & 51.16 \\
\hline
\end{tabular}

*Within columns differences were not significantly different

The two types of progestagens used in this trial were equally efficient in synchronizing oestrus in does. Similar findings were observed by Freitas et al. (1996b; 1997) and Motlomelo et al. (2002). On the other hand, the oestrus response obtained in this study was higher than the $73.5 \%$ reported by Greyling \& Van der Nest (2000), using intravaginal MAP progestagen sponges.

Researchers have reported the onset of oestrus to occur within 6-120 h following progestagen withdrawal (Freitas et al., 1996a; Romano, 1998; Greyling \& Van der Nest, 2000). In this study, the overall mean interval to onset of oestrus following progestagen removal was $15.4 \pm 0.5 \mathrm{~h}$ and was not significantly different between the MAP and the FGA groups (Table 1). However, this interval was relatively shorter than those reported by Freitas et al. (1996a,b), Romano (1996), Freitas et al. (1997), Romano (1998), Ak et al. (1998), Greyling and Van der Nest (2000) and Motlomelo et al. (2002) in does. These differences may be explained by the differences in breed, lactation, nutrition, season, use of gonadotrophins, presence of females in pro-oestrus/oestrus and presence of the male after sponge removal that are known to influence this parameter (Doney et al., 1973; Greyling \& Van Niekerk, 1990; Mani et al., 1992; Romano, 1998; Ahmed et al., 1998; Romano, 2002).

Longer oestrus duration in does treated with FGA sponges $(34.0 \pm 1.4 \mathrm{~h})$ was recorded when compared to MAP sponges $(30.5 \pm 1.9 \mathrm{~h})$. Type of progestagen thus had no significant effect on the duration of the induced oestrus period. The mean duration of the induced oestrus $(32.5 \pm 1.2 \mathrm{~h})$ obtained in this study is in line with that reported by Romano (1996), Geyling \& Van der Nest (2000) and Motlomelo et al. (2002).

The overall mean interval from sponge withdrawal to cessation of oestrus was $42.8 \pm 1.0 \mathrm{~h}$ and no difference was observed for mean time to cessation of oestrus between the treatment groups. This is in agreement with data obtained by Freitas et al. (1996a) and Freitas et al. (1997), but was shorter than the periods reported by Baril et al. (1993), Romano (1998) and Greyling \& Van der Nest (2000). These differences may be due to the different techniques used in these studies.

None of the two progestagen treatments showed any significant advantage over the other with respect to conception rate (52.63 and 50.0\% for MAP and FGA groups, respectively). The overall pregnancy rate at 53 days following AI for all does in this study was $51.2 \%$. This is similar to the result reported by Motlomelo et al. (2002) and lower than that reported by Freitas et al. (1996a), Romano (1996) and Greyling \& Van der Nest (2000). In the present study, AI in synchronized does was carried out at a fixed time following sponge withdrawal, which could imply that the difference in the conception rate could be due to the differences in the time of occurrence of oestrus and the set time of AI (Baril et al., 1993). In the present study, the low conception rate recorded could be attributed to the inseminations being executed too late.

\section{Conclusions}

The South African Journal of Animal Science is available online at http://www.sasas.co.za/Sajas.html 
The progesterone treatments with the aid of MAP and FGA intravaginal progestagen sponges are almost equally efficient in synchronizing oestrus in lactating Saanen does during the transition from nonbreeding to the natural breeding season. Although low, the conception rates obtained justify further investigation.

\section{Acknowledgements}

The authors would like to thank H. Karagoz and M. Ozdemir for their assistance.

\section{References}

Ahmed, M.M.M., Makawi, S.E. \& Jubara, A.S., 1998. Synchronization of oestrus in Nubian goats. Small Rumin. Res. 30, 113-120.

Ak, K., Ozturkler, Y., Kasikci, G., Horoz, H., Kilicarslan, R. \& Ileri, I.K., 1998. Ankara kecilerinde farkli ostrus senkronizasyonu yontemleri ve serum progesteron, LH seviyeleri uzerinde arastirmalar. J. Fac. Vet. Med. Univ. Istanbul. 24, 367-377.

Alifakiotis, T., Michailidis, I. \& Gavrilidis, G., 1982. Induced breeding in anestrus milking ewes of dairy breeds: comparison of norgestomet, medroxyprogesterone and fluorgestone in two regimes of PMSG. Theriogenology 17, 603-610.

Baril, G., Leboeuf, B. \& Saumande, J., 1993. Synchronization of estrus in goats: the relationship between time of occurrence of estrus and fertility following artificial insemination. Theriogenology 40, 621628.

Boland, M.P., Kelleher, D. \& Gordon, I., 1978. Comparison of control of oestrus and ovulatin in sheep by ear implant (SC-21009) or by intravaginal sponge (cronolone or MAP). Anim. Reprod. Sci. 1, 275281.

Bretzlaff, K., 1997. Control of the estrous cycle. In: Current therapy in large animal theriogenology. Ed. Youngquist, R.S., W.B. Saunders Company, Philadelphia. pp. 510-514.

Chemineau, P., Malpaux, B., Delgadillo, J.A., Guerin, Y., Ravault, J.P., Thimonier, J. \& Pelletier, J., 1992. Control of sheep and goat reproduction: use of light and melatonin. Anim. Reprod. Sci. 30, 157-184.

Doney, J.M., Gunn, R.G. \& Griffiths, J.G., 1973. The effect of premating stress on the onset of oestrus and on ovulation rate in Scottish Blackface ewes. J. Reprod. Fertil. 35, 381-384.

Freitas, V.J.F., Baril, G. \& Saumande, J., 1996a. Induction and synchronization of estrus in goats: the relative efficiency of one versus two fluorogestone acetate-impregnated vaginal sponges. Theriogenology 46, 1251-1256.

Freitas, V.J.F., Baril, G., Bosc, M. \& Saumande, J., 1996b. The influence of ovarian status on response to estrus synchronization treatment in dairy goats during the breeding season. Theriogenology 45 , 1561-1567.

Freitas, V.J.F., Baril, G. \& Saumande, J., 1997. Estrus synchronization in dairy goats: use of fluorogestone acetate vaginal sponges or norgestomet ear implants. Anim. Reprod. Sci. 46, 237-244.

Gordon, I., 1975. The use of progestagens in sheep bred by natural and artificial insemination. Ann. Biochim. Biophys. 15, 303-315.

Greyling, J.P.C. \& Van der Nest, M., 2000. Synchronization of oestrus in goats: dose effect of progestagen. Small Rumin. Res. 36, 201-207.

Greyling, J.P.C. \& Van Niekerk, C.H., 1990. Effect of pregnant mare serum gonadotrophin (PMSG) and route of administration after progestagen treatment on estrus an $\mathrm{LH}$ secretion in the Boer Goat. Small Rumin. Res. 3, 511-516.

Leboeuf, B., Manfredi, E., Boue, P., Piacére, A., Brice, G., Baril, G., Broqua, C., Humblot, P. \& Terqui, M., 1998. Artificial insemination of dairy goats in France. Livest. Prod. Sci. 55, 193-203.

Mani, A.U., McKelvey, W.A.C. \& Watson, E.D., 1992. The effects of low level of feeding on response to synchronization of oestrus, ovulation rate and embryo loss in goats. Theriogenology. 38, 1013-1022.

Motlomelo, K.C., Greyling, J.P.C. \& Schwalbach, L.M.J., 2002. Synchronisation of oestrus in goats: the use of different progestagen treatments. Small Rumin. Res. 45, 45-49.

Romano, J.E., 1996. Comparison of fluorgestone and medroxyprogesterone intravaginal pessaries for estrus synchronization in dairy goats. Small Rumin. Res. 22, 219-233.

Romano, J.E., 1998. The effect of continuous presence of bucks on hastening the onset of estrus in synchronized does during the breeding season. Small Rumin. Res. 30, 99-103. 
(C) South African Society for Animal Science

Romano, J.E., 2002. Does in proestrus-estrus hasten estrus onset in does estrous synchronized during breeding season. Appl. Anim. Behav. Sci. 77, 329-334.

Smith, P.A., Boland, M.P. \& Gordon, I., 1981. Effect of type of intravaginal progestogen treatment on outcome at fixed time artificial insemination. J. Agric. Sci., Camb. 96, 243-245. 